\title{
Varieties of contestation: The comparative and critical political economy of 'excessive' demand
}

\author{
David J. Bailey
}

University of Birmingham, UK

\section{Saori Shibata}

University of Birmingham, UK

\begin{abstract}
This paper agrees with much of the current criticism, especially from Marxist perspectives, which argues that the varieties of capitalism ( $\mathrm{VoC}$ ) approach overemphasises the degree of harmony and mutual benefit, as well as the absence of class tension and exploitation, within contemporary capitalist relations. It also, however, criticises many of these Marxist critiques on the grounds that they too willingly accept that relations of domination and exploitation are constitutive of contemporary capitalism. In contrast, the present paper draws on alternative positions within the heterodox Marxist tradition to highlight the contestation that invariably disrupts attempts to structure relations of exploitation and domination. Rather than varieties of capitalism, or varieties in capitalism, therefore, we might be better served by seeking to map varieties of contestation. These arguments are developed with reference to empirical sketches of patterns of contestation in Japan and the UK. These are two countries typically considered alternative types of market economy, but instead considered here to evince contrasting patterns of contestation.
\end{abstract}

\section{Keywords}

Capitalism, heterodox Marxism, minor Marxism, contestation, disruption

\section{Corresponding author:}

David J. Bailey, University of Birmingham, UK.

Email: d.j.bailey@bham.ac.uk 


\section{Introduction}

Much has been written about the multiple, mutually reinforcing and potentially complementary institutional conditions that constitute particular varieties of capitalism (Hall \& Soskice 2001; Iversen 2005). This literature has rightly identified the absence of a single path to achieving economic efficiency and productivity. In response, however, a subsequent body of research has emerged to critique the appearance of harmony and mutual benefit, as well as the absence of class tension and exploitation, provided by much of the mainstream literature, especially in its varieties of capitalism (VoC) form (see also numerous papers in this special issue). Attempts to conceptualise varieties of capitalism, so this latter critique claims, must take into account the relations of domination and exploitation that constitute capitalism, and the pressures, processes and commonalities that exist across each of these varieties. Not only do we need to recognise varieties of capitalism and the institutional complementarities that constitute these varieties, but we must also recognise that they each form a part of capitalism, and therefore face common pressures to reproduce the social relations of capitalist production that they in part constitute.

Thus, 'there are varieties of capitalism, but they are varieties in capitalism as well' (Bruff 2011: 482; emphases in original). This includes a focus on constant competitive pressure and the ever-present search for increased relative surplus value, which it is claimed produces a tendency to expanded commodification and/or intensify exploitation, thereby undermining attempts to stabilise capitalist relations (cf. Aglietta 1979; Boyer 2005; Coates 2005). A focus on the different manifestations that capitalist production might take within different national political economies (i.e. the position advanced by comparative capitalisms [CC] approaches, especially the VoC framework) risks obscuring important trends, relations, pressures and tendencies that exist across each of these different models. Thus, Bruff (2011: 488) notes the importance of understanding the way in which ideas, institutions and (therefore) agency are 'grounded in the system of production', resulting in a structural inequality of interest prioritisation (i.e. the reproduction of capital is prioritised over the interests of labour). In sum, therefore, despite the existence of a variety of forms of capitalism, key factors - structured inequality, exploitation, domination, and instability - continue to exist in each of the varieties, alongside consistent pressure for their increase, expansion or intensification.

The conceptual clarification offered by this critique is largely to be welcomed, particularly in re-focusing our attention on the means by which relations of production and exploitation are structured within particular varieties of capitalism. The present paper, however, draws on alternative positions within the critical political economy literature in order to highlight the contestation that invariably disrupts such attempts to structure relations of production and exploitation within particular varieties of capitalism. Rather than varieties of capitalism, or varieties in capitalism, therefore, we might be better served by seeking to map varieties of contestation. As such, a focus on the structured nature of domination in different capitalist societies risks overplaying the systemic capacity for domination, and under-emphasising the scope for effective resistance to, or disruption of, this capacity. There is a risk, in the words of Jason Read, that despite its intention to challenge capitalism and the exploitation and domination it entails, critical political 
economy nevertheless seems to 'masochistically delight in the image of the pervasive power of capital' (Read 2003: 14).

Thus, the paper takes issue with this emergent consensus within the critical political economy literature, drawing on an alternative position within the broad critical political economy tradition, sometimes termed 'minor Marxism' (Holland 2011: 128). According to this alternative position, the 'critical' in critical political economy should be less concerned with identifying relations of domination and exploitation, and more focused on the problems associated with sustaining such relations (see also Gough in this special issue). This approach therefore contrasts with that of Boyer (2011), who posits a number of 'laws of motion of capitalism', including the centrality of capital accumulation to the process of economic activity, the destabilising, expansionary and commoditising effects this produces, and the crisis-prone nature of such a system. Such a view, we argue, risks 'a passive interpretation' focused on what Cleaver refers to as 'the system's mysterious economic "laws of motion" that regulate the behaviour of the capitalist class', and in which the working class, 'When it appears on the scene at all, it comes in from the outside and usually as a victim fighting defensive battles' (Cleaver 1979: 26-7).

\section{Varieties of contestation}

Marx's own work can be (and has been) read in terms of its attempt to highlight the unavoidably active and disruptive nature of the working class (Eden 2012; Read 2003; Cleaver 1979; Lebowitz 1992; Negri 1991). Accordingly, rather than being considered as the actions of victims confronted by all-powerful agents of domination and exploitation, workers' activity is rather conceptualised as the source of the inability of capital to reproduce itself. Put simply, capitalism is crisis; but the worker is the culprit, not the victim, of that crisis. Thus, as Marx shows, the exchange and consumption of the commodity of labour power is essential to the process of capitalist reproduction, due to its unique ability to generate surplus value. But consumption of the commodity, labour power, is also the most problematic of the elements of the process of capitalist reproduction. As Marx (1976: 342) has the worker point out to the capitalist, "The commodity I have sold you differs from the ordinary crowd of commodities in that its use creates value, a greater value than it costs. That is why you bought it. What appears on your side as the valorization of capital is on my side an excess expenditure of labour power'.

As a result, the working day (and indeed all activity within the workplace) is invariably contested, as much of the labour process theory literature has consistently argued (Knights \& Wilmott 1990; Böhm \& Land 2012). The capitalist seeks to maximise surplus value, the worker to avoid working beyond (and, indeed, up to) the exchange value she receives for her labour power: 'Hence in the history of capitalist production, the establishment of a norm for the working day presents itself as a struggle over the limits of that day, a struggle between collective capital, i.e. the class of capitalists, and collective labour, i.e. the working class' (Marx 1976: 344). The share of the spoils of production is thus entirely up for grabs and 'depends on the relative weight thrown into the scale by the pressure of capital on the one side, and the resistance of the worker on the other' (Marx 1976: 659). 
Any attempt, therefore, to commodify labour power - i.e. to turn the labour expended by workers into a material thing (the exchange value of which is determined by the socially necessary labour time required to produce it) - should be considered problematic on two counts. First, it is an attempt to ascribe objective and externallyderived qualities outside of human control to socially-produced entities - i.e. it portrays 'the social characteristics of men's own labour as objective characteristics of the products of labour themselves', and therefore is 'nothing but the definite social relation between men [sic] themselves which assumes here [in capitalism], for them, the fantastic form of a relation between things' (Marx 1976: 164-5). Second, in the act of consuming the commodity of labour power, the commodity's own materiality is itself contestable in a way that clearly differs from commodities such as food, cars or clothes. The commodification of the worker's labour power, therefore, is both essential to the reproduction of capitalism and (doubly) problematic. As a social relation, its commodification is always-already an unsustainable act of reification; and its 'consumption' is inherently contestable and invariably contested. It is on this basis, therefore, that we argue here that a sounder engagement with the varieties of capitalism literature would seek to conceptualise not varieties of capitalism, nor varieties in capitalism, but rather varieties of contestation.

In beginning to think in terms of varieties of contestation, we draw on some of the insights developed in the work of Deleuze and Guattari, who were arguably closer to Marx's position regarding the problematic nature of capitalist reproduction than some of the more orthodox adherents to the Marxist canon (Bailey 2010: 333). Thus, Deleuze and Guattari recognised the inherently disruptive nature of the proletariat, as well as the conservative implications of viewing this disruptive potential through a perspective that presumes incorporation rather than disruption:

The power of minority, of particularity, finds its figure or its universal consciousness in the proletariat. But as long as the working class defines itself by an acquired status, or even by a theoretically conquered State, it appears only as 'capital', a part of capital (variable capital), and does not leave the plan(e) of capital. At best, the plan(e) becomes bureaucratic. On the other hand, it is by leaving the plan(e) of capital, and never ceasing to leave it, that a mass becomes increasingly revolutionary and destroys the dominant equilibrium of the denumerable sets. (Deleuze \& Guattari 1988: 521; emphasis in original)

Along with Marx, Deleuze and Guattari recognise the disruptive potential of the proletariat, provided that it struggles against its ascribed proletarian status. It is the inherent and ever-present capacity to voice desire and make demands, beyond those permitted of commodified labour, that provides the worker with her disruptive and therefore revolutionary capacity. Rather than seek to describe modes of domination, therefore, Deleuze and Guattari highlight the impossibility of capture - the ever-present and ultimately uncontainable 'line of flight'. Thus, social assemblages are constituted, but also disrupted, by desire, or what we might consider 'excessive' demand. There exists within all social assemblages, therefore, a dynamic interaction between, on the one hand, contestation, disruption and an 'excess' of demands; and on the other, the (always-already failing) attempt to capture and contain that desire (Bailey 2010: 334-5). 
Some of the insights within Deleuze and Guattari's work are also associated with developments within the autonomous Marxist tradition. For instance, Hardt and Negri (2009) discuss notions of 'exodus' and 'lines of flight' in a form that applies the insights of Deleuze and Guattari to the capital-labour relation, whereby we witness a movement that is 'actualizing the potential autonomy of labour power' (2009: 162). Similarly, Read (2003) discusses the necessary and problematic construction of subjectivity in contemporary capitalism, and the excess of desire that this unavoidably produces (2003: 11), plus 'the deepening conflict over the subjectivity and sociality of labor' that results (2003: 17). Finally, Papadopoulos et al. (2008; see also Tsianos et al. 2012) focus on acts of contention and the way in which these acts should be considered primary to subsequent attempts at containment and control. Thus, 'Sovereignty manifests itself in response to escape. People do not escape their control. People escape. Control is a cultural-political device which comes afterwards to tame and eventually to appropriate people's escape. Social struggles come first' (Papadopoulos et al. 2008: 43). Building on this insight, the authors develop the concept of 'imperceptible politics', referring to the subversive acts of disobedience which always-already exist beyond apparatuses of capture and which therefore constantly disrupt and motivate changes to those apparatuses (Tsianos et al. 2012).

In drawing these insights together, we argue that an approach which seeks to conceptualise varieties of contestation (in contrast with both varieties of, and in, capitalism) should be characterised by three key features. First, workers' actions are considered proactive and primary, rather than reactive responses to domination. As such, we consider varieties of demands, disruption, and contestation to be the primary phenomenon to be observed, with attempts to constrain and contain such acts considered to be reactions (and of secondary importance). Second, rather than focusing on the way in which domination is secured through hegemonising acts, varieties of contestation should instead be understood in terms of the inability to secure hegemony (for a contrasting approach, see also Kannankulam \& Georgi in this special issue). Mechanisms of containment, integration and co-optation are therefore understood and conceptualised as secondary, porous and incomplete. Finally, we seek to identify alternative ways in which this primacy of labour, and the secondary (but necessarily incomplete) status of attempts at containment, manifest themselves empirically. Thus, we wish to map empirically the alternative ways in which these processes have occurred in different contexts (in much the same way that the CC literatures highlight empirical patterns associated with the different contexts with which they are interested).

What follows, therefore, is an attempt to explore these primary and secondary dimensions. We provide sketches that highlight empirical patterns in two countries typically considered representative of the two alternative 'types' constructed by the VoC framework: Japan (as an example of a coordinated market economy [CME]) and the UK (an example of a liberal market economy [LME]). ${ }^{1}$ Yet, rather than attempt to identify the particular mechanisms of coordination (market vs. strategic) considered within the VoC literature, we instead seek to map patterns of contestation and secondary (and incomplete) attempts to contain that contestation. In contrast to approaches that foresee either a viable $(\mathrm{VoC})$ or an exploitative ( $\mathrm{ViC}$ [varieties in capitalism]) model of capitalism, therefore, we instead portray creative acts of contestation, which are followed by the development of incomplete models of containment (or, in Deleuze and Guattari's terms, 
'apparatuses of capture') that are nevertheless subsequently disrupted and contested by workers refusing and resisting (in different ways) attempts to ensure their commodification. Further, by focusing especially on contexts and times when we are led within the $\mathrm{VoC} / \mathrm{ViC}$ literature to anticipate low levels of disruption or contestation - either because coordination is considered to have been secured (in the case of Japan) or consent constructed (in the case of the post-1980s UK), we are able to highlight, through the brief empirical overviews provided, the potential for analytical and empirical insights gained through the alternative 'varieties of contestation' approach advanced herein. Further, as we shall see, and although these insights will need to be developed at greater length in subsequent studies, the empirical analyses informed by this minor Marxism approach highlight the role of alternative forms of social contestation, and the respective attempts to secure their containment, in producing the major rupture of global capitalist relations that marked the post-2008 global economic crisis.

\section{Japan}

Emerging from the Second World War, Japan's industrial relations witnessed a rapid outbreak of widespread and disruptive acts of labour militancy between 1945 and 1947, as union membership rose from almost nothing to around 5 million workers, who took part in a series of high-profile and largely successful pay-related disputes, and over 150,000 of whom participated in more than 250 incidents of 'production-control' whereby factories were taken over and managed by workers (Gordon 1985: 331-2). In attempting to control and contain this outbreak of militancy, the Supreme Commander for the Allied Powers (SCAP) and Japan's management elite responded by constructing a system of labour relations that was to last for much of the postwar period, and to coincide with a period of sustained economic growth. This was based largely on four key mechanisms, or 'axioms' (Holland 2011: 129), whereby attempts were made to construct a consensus or loyalty-based model of industrial relations, and thereby address the breakdown of control that emerged in the immediate post-war period.

First, Japan's postwar model sought to inculcate loyalty to the firm, combining high levels of employment security, a seniority wage system which disincentivised workers from making career or firm changes (Isogai et al. 2000: 35), and the attempt to propagate a culture that would value loyalty to the firm. Second, the wages policy associated with this approach included a commitment to expanding monetary reward as an additional means by which to seek to integrate workers (Isogai et al. 2000; Tohyama 2000; Uni 2000). Third, employers and the political elite sought to develop a commitment amongst workers to delayed gratification, whereby rewards would be reaped later in exchange for the suppression of demands in the present. Thus, there existed a relatively high savings rate in Japan through much of the growth era, although this eased off during the 1970-90 period (Uemura 2000: 149), and a commitment to a seniority wage system sought to ensure the containment of workers' demands at the beginning of their careers in exchange for financial rewards at a later stage. Finally, SCAP and Japanese government and employers acted to encourage membership of bureaucratic enterprise unions (i.e. unions directly linked to the company within which they were based) in an attempt to marginalise more radical unions and limit workers' demands. 
Each of these additional axioms, however, as anticipated on the basis of the foregoing discussion, proved unable to sufficiently contain workers' demands. Most immediately, the wage share secured by workers was such that profits were eventually reduced to unsustainable levels (the profit rate dropped from a peak of more than 30 per cent at the end of the 1960s to between 15 per cent and 20 per cent between 1975 and 1990 [Uni 2000: 56; Boyer \& Julliard 2000: 134]). This decline in profit rates was partly compensated for during the 1980 s by a process of financial deregulation and an asset (especially land and property) bubble, although this in turn eventually burst in 1990, resulting in Japan's lost two decades. Thus, attempts to integrate workers' demands through a combination of financial reward, employment security and rising asset prices proved untenable, as the excess of demands and desires that constituted the Japanese social assemblage during this period proved to be excessively disruptive in limiting the scope for profit-making.

Reacting to these 'excessive' demands, Japanese employers sought from the early 1990s onwards to re-impose the discipline of what Deleuze and Guattari refer to as the 'capitalist axiomatic', through a firmer reliance upon the market and a growing reluctance to guarantee rising wages and employment security. For example, we witness an explicit attempt by Nikkeiren (Japan Federation of Employers' Associations) from 1995 onwards to expand the use of non-regular temporary employment, producing a rise in temporary non-regular workers (from around 19 per cent of the workforce in 1990 to around 24 per cent in 1999), more flexible working hours, increasing use of a performance-based payment system, an end to the lifetime employment system, a decline in the seniority wage curve, increased wage inequality, and a reduction in paid overtime (Suzuki et al. 2010: 532; Mouer \& Kawanishi 2005: 106; Shimizutani \& Yokoyama 2009: 3223; Yun 2010: 2; White Paper on Labour Economy 2010: 77). Japanese workers, however, moved increasingly to contest and disrupt the more marketised wage relation brought about by these changes.

Thus, Japanese workers' demands were expressed in an increasingly frequent and antagonistic form from the 1990s onwards, following the introduction of the marketised reforms. ${ }^{2}$ We witness a rise in the number of demonstrations and protests, a growth in industrial and legal disputes, and a heightened focus on collective bargaining throughout this period. Notably, workers' demands also began to move away from the more formal axioms of incorporation that had been pursued during the pre-1990 period, including a shift from institutionalised May Day protest events as the only means by which the workers' collective voice would be expressed, and also the sharp rise in what Holland (2011) might refer to as forms of 'nomad citizenship', whereby citizens and workers mobilise autonomously of the state and in less hierarchical forms, thus witnessing an increased frequency of acts of resistance organised by groups such as community unions, NPOs (non-profit organisations), self-organised workers, and non-regular workers. In part as a result of this increased militancy, wage demands continued to result in the wage share rising through the 1990s, to around 75 per cent, where it remained during the 2000s despite sluggish growth (White Paper on Labour Economy 2008).

\section{UK}

In contrast to the Japanese experience, the UK economy experienced more visible and continuous disruption in the form of ongoing militant and unofficial industrial action 
throughout much of the postwar period, with around 95 per cent of all strikes being unofficial by the late-1960s (Cohen 2006: 10; Panitch 1976: 90-5). Attempts by successive governments to contain these unpermitted and excessive expressions of demand were largely unsuccessful. The Labour government's proposed 'In Place of Strife' White Paper prompted an outpouring of labour militancy, largely coordinated by the Liaison Committee for the Defence of Trade Unions (which acted as a potential rival to the more moderate TUC), which eventually resulted in a climbdown by the government (Davis 2009: 270-2). Similarly, the attempt to criminalise unofficial industrial action by the Heath government, through its adoption of the 1971 Industrial Relations Act, and the subsequent arrest of five striking dock workers (the Pentonville Five), resulted in a response whereby 'at least 170,000 workers came out in their support, creating what could have been - and almost was - a TUC-led general strike', and in which the government again retreated, this time by releasing the prisoners (Cohen 2006: 22). And finally, the 17 per cent pay settlement won by striking Ford workers in 1978, and subsequent move to widespread industrial militancy, prompted the collapse of the Labour government's Social Contract (Rhodes 2000: 35), in the process highlighting the difficulties associated with attempts to limit and contain workers' (excessive) demands.

Reacting to these developments, the post-1979 Conservative governments sought to regain control through the introduction of legislation to regulate industrial disputes (Baccaro \& Howell 2011: 537). This was combined with market-oriented social reforms such as the right to buy and the privatisation of public utilities, which sought to inculcate an affinity with a smoothly-functioning market economy, or what Read (2003) would refer to as a 'subjectivity' more suited to a liberal mode of production. Despite such attempts at containment, however, significant economic and extra-economic (or sociopolitical) disruptions continued in workplaces and working-class communities, including the urban riots of the early 1980s in Brixton, Broadwater Farm, Bristol, and Liverpool; the 1984-5 miners' strike; the 1986 Wapping industrial dispute; and the mass disobedience around the introduction of the poll tax. Such trends continued into the 1990s, witnessing militant environmentalist campaigns, the illegal rave scene and violent protests such as those witnessed in opposition to the Criminal Justice Bill in 1994.

From 1997, the election of the New Labour government witnessed an attempt to move towards a more inclusive mode of containment, especially through the introduction of new rights in the workplace, such as a statutory minimum wage, greater protection from unfair dismissal, (conditional) entitlement to union recognition, and enhanced grievance procedures (Baccaro \& Howell 2011: 538). Alongside this more inclusive approach, attempts to contain demands through marketisation and a firmer assertion of the capitalist axiomatic also continued, including for instance the adoption of a new asset-based model of welfare'. Here, government support for an inflationary housing market sought essentially to privatise welfare provision through the construction of an expanding home-owning population that could rely on increased house prices to fund elderly care, and thereby allow 'British households to consume at a rate that exceeded their income from paid work' (Watson 2008: 286, 291).

'Excessive' demands, however, continued to disrupt these more inclusive attempts to reproduce British capitalism under the management of New Labour. Thus, as has since become readily apparent, New Labour's mode of control was unsustainable, as 


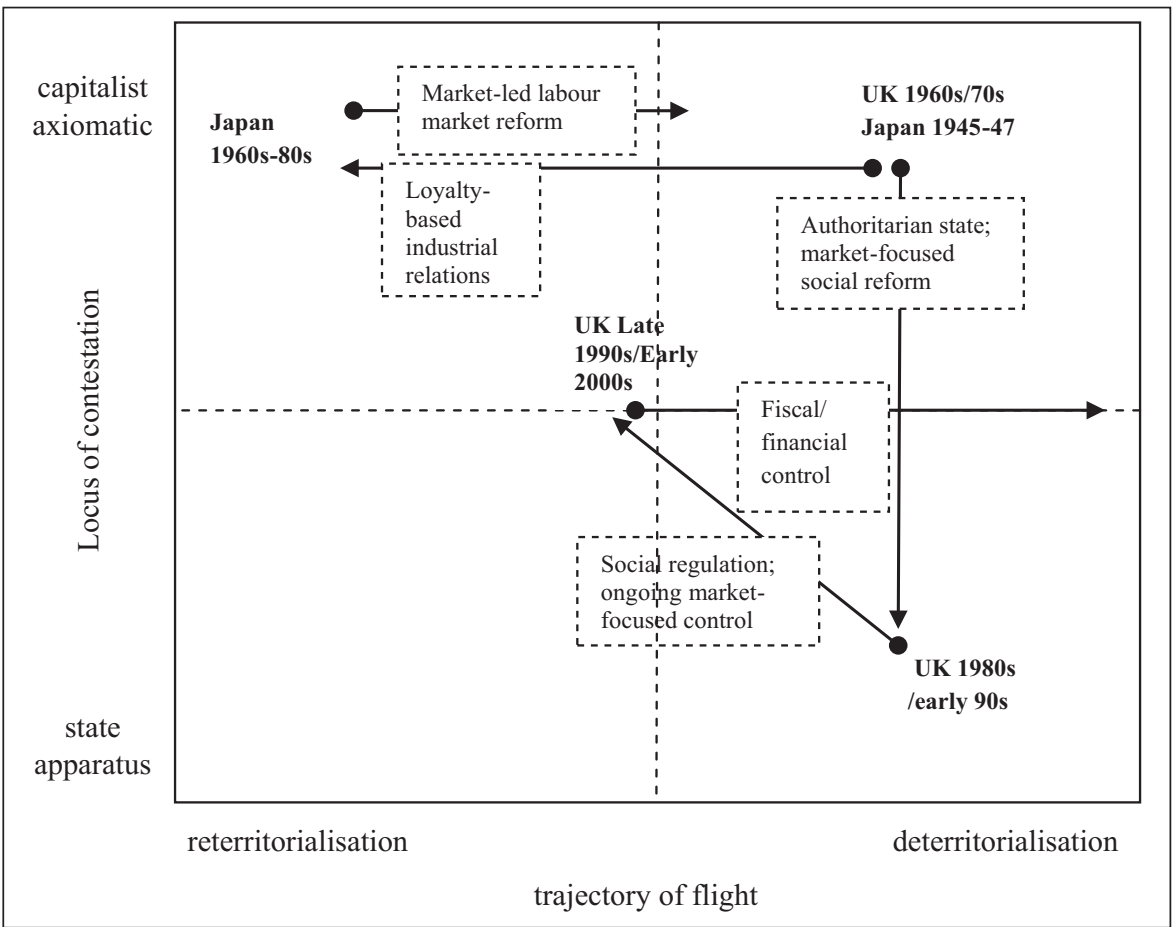

Figure 1. Varieties of contestation in Japan and the UK.

'excessive' demand was effectively monetised in the form of a financial and housing market bubble and resulted in the post-2007 bursting of the economic bubble. Moreover, the subsequent attempt following the crisis to impose fiscal and income discipline and austerity measures, in the guise of financial necessity in a context of economic stagnation and excessive public debt (Stanley 2012), has witnessed a period characterised by a return to heightened levels of disruption and protest. This has included factory occupations, a wave of unofficial industrial action focused around the Lindsey Oil Refinery, the public-sector pensions dispute, the student protest movement, a wave of civil disobedience targeting UK tax avoidance (UK Uncut), and the re-emergence of urban riots in August 2011.3

\section{Conclusion}

In an attempt to sum up the foregoing discussion, Figure 1 presents an initial mapping of the broad trends discussed above. The figure highlights two dimensions. The vertical dimension charts the 'apparatuses of capture' being disrupted. This is marked by a distinction between contestation of, on the one hand, what Deleuze and Guattari refer to as the 'capitalist axiomatic', which we might consider to have at its core the exchange relation underpinned by the extraction of surplus value (Holland 2011: 129); and on 
the other hand contestation of the state apparatus, which Deleuze and Guattari (1988: 508) term the moment when the state seeks 'capture, bond, knot, nexum, magical capture' (that is, the point at which the state seeks to regulate and control its citizens). The horizontal dimension, in contrast, divides between antagonisms that are more disruptive and deterritorialising and those which are partially integrated and reterritorialised. In each case, the figure highlights the primacy of contestation, as 'excessive' workers' demands (depicted by the arrows) prompt attempts at containment (represented by the dashed boxes) that in turn produce a move towards new forms of contestation.

In the Japanese case, therefore, we witness the move from disruptive and deterritorialising industrial action in the early postwar period, to an excess of demands reterritorialising within the loyalty-based model of Japanese industrial relations. This in turn, as we observed, resulted in an attempt to contain those demands through a move towards market-oriented labour market reform, and a re-assertion of the capitalist axiomatic, which has prompted a (partial) move back in the direction of disruptive and antagonistic, deterritorialising, labour disputes. In the case of the UK, we witness a similar starting point: during the 1960s and 1970s there were waves of largely unofficial, deterritorialising, industrial disputes, the containment of which was eventually sought by Thatcher through the combination of a 'strong state' and market-oriented social reforms (Gamble 1994), but which failed to contain an outpouring of disruptive acts that were largely of a political and socioeconomic nature and challenged the capture of the state apparatus. As the figure shows, the New Labour period subsequently witnessed an attempt to secure consent in this context through a combination of social regulation and limited labour rights, combined with an expansion of market-oriented social control, although this in turn prompted the reterritorialisation of excessive demands within rising asset and property prices. Whilst the coalition government has sought to impose fiscal and financial control through recourse to the notion of collective responsibility for public debt and economic 'hard times' (Stanley 2012), the outcome has been a return of both industrial and civil disruption.

Rather than seeking to compare and conceptualise the dichotomous characteristics and causal dynamics of CMEs versus LMEs, therefore, we suggest a contrasting starting point which highlights the alternative ways in which contestation occurs, how its containment is sought, and the subsequent acts of disruption that occur as a response. As such, and based on Figure 1, an alternative dichotomy that we might consider for our starting point is that between the disruption of attempts to reterritorialise contestation upon the capitalist axiomatic, as identified for much of the Japanese case, compared with the deterritorialisation that disrupts attempts to impose mechanisms of state capture, as identified for much of the UK case.

In sum, by focusing on varieties of contestation, rather than varieties of capitalism or varieties in capitalism, we can develop an alternative critical and comparative political economy that highlights patterns of contestation and disruption. In focusing on such patterns of contestation, therefore, we avoid a somewhat restrictive opposition between 'innocent' varieties of capitalism (that fail to sufficiently conceptualise capitalist relations) and 'gloomy' varieties in capitalism (that posit capitalism as a [complete] process of domination), and instead suggest that we might instead consider varieties of 
contestation in order to explain variation, conceptualise capitalist relations, and avoid an overbearing preoccupation with the defeat of the social agent through which positive social change is anticipated. Indeed, such patterns of contestation provide insights into the ways in which social change can be (or, more accurately, is being) brought about, and might otherwise be missed by comparative and critical political economy.

\section{Acknowledgements}

The authors are grateful for the helpful comments and suggestions provided by the anonymous reviewer, the special issue editors, Ian Bruff and Matthias Ebenau, and the comments of the participants and organisers at the 'Critical Perspectives on the Diversity of Contemporary Capitalism(s)' workshop in Wiesbaden, Germany, 10-11 February 2012.

\section{Endnotes}

1. Space does not permit a more extensive exploration of Japan's place in CC debates on capitalist diversity. However, although we use the $\mathrm{VoC}$ literature as the entry point into the below discussion, it should be noted that across a range of contributions to the CC literatures, Japan is commonly viewed as having a rather different type of capitalism to those found in AngloSaxon countries (e.g. Streeck \& Yamamura 2001, 2003). The end result is similar, though: the relative absence of contestation from the analysis.

2. This empirical discussion draws on event data analysis conducted by one of the authors, Saori Shibata, as part of her doctoral research.

3. This draws on empirical research presented in Bailey (2011).

\section{References}

Aglietta M (1979) A Theory of Capitalist Regulation: The US Experience. London: Verso.

Baccaro L, Howell C (2011) A common neoliberal trajectory: The transformation of industrial relations in advanced capitalism. Politics and Society 39(4): 521-63.

Bailey D (2009) The Political Economy of European Social Democracy: A Critical Realist Approach. London: Routledge.

Bailey D (2010) The European rescue, recommodification, and/or reterritorialization of the (becoming-capitalist) state? Marx, Deleuze, Guattari, and the European Union. Journal of International Relations and Development 13(4): 325-53.

Bailey D (2011) Extra-parliamentary politics after crisis: The (belated) birth of social movement society Britain? Paper presented at the European Consortium for Political Research general conference, Reykjavik, Iceland, 25-27 August.

Böhm S, Land C (2012) The new 'hidden abode': Reflections on value and labour in the new economy. Sociological Review 60(2): 217-40.

Boyer R (2005) How and why capitalisms differ. Economy and Society 34(4): 509-57.

Boyer R (2011) Are there laws of motion of capitalism? Socio-Economic Review 9(1): 59-81.

Boyer R, Julliard M (2000) The wage labour nexus challenged: More the consequence than the cause of the crisis. In Boyer R, Yamada T (eds.) Japanese Capitalism in Crisis: A Regulationist Interpretation. London: Routledge.

Bruff I (2011) What about the elephant in the room? Varieties of capitalism, varieties in capitalism. New Political Economy 16(4): 481-500.

Cleaver H (1979) Reading Capital Politically. Brighton: Harvester.

Coates D (2005) Paradigms of explanation. In Coates D (ed.) Varieties of Capitalism, Varieties of Approaches. Basingstoke: Palgrave Macmillan. 
Cohen S (2006) Ramparts of Resistance: Why Workers Lost Their Power and How To Get It Back. London: Pluto.

Davis M (2009) Comrade or Brother? A History of the British Labour Movement. London: Pluto.

Deleuze G (1995) Negotiations: 1972-1990, trans. Joughin M. New York: Columbia University Press.

Deleuze G, Guattari F (1988) A Thousand Plateaus: Capitalism and Schizophrenia, trans. Massumi B. London: Athlone.

Eden D (2012) Autonomy: Capitalism, Class and Politics. Surrey: Ashgate.

Gamble A (1994) The Free Economy and the Strong State: The Politics of Thatcherism (2nd ed.). London: Macmillan.

Gordon A (1985) The Evolution of Labor Relations in Japan: Heavy Industry, 1853-1955. Cambridge, MA: Harvard University Press.

Hall PA, Soskice D (2001) An introduction to varieties of capitalism. In Hall PA, Soskice D (eds.) Varieties of Capitalism: The Institutional Foundations of Comparative Advantage. Oxford: Oxford University Press.

Hardt M, Negri A (2009) Commonwealth. Cambridge, MA: Belknap Press of Harvard University Press.

Holland EW (2011) Nomad Citizenship: Free Market Communism and the Slow-Motion General Strike. Minneapolis: University of Minnesota Press.

Isogai A, Ebizuka A, Uemura H (2000) The hierarchical market-firm nexus as the Japanese mode of regulation. In Boyer R, Yamada T (eds.) Japanese Capitalism in Crisis: A Regulationist Interpretation. London: Routledge.

Iversen T (2005) Capitalism, Democracy, and Welfare. Cambridge: Cambridge University Press.

Marx K (1976) Capital: A Critique of Political Economy. Volume One, trans. Fowkes B. London: Penguin.

Mouer R, Kawanishi H (2005) A Sociology of Work in Japan. Cambridge: Cambridge University Press.

Negri A (1991) Marx Beyond Marx: Lessons on the Grundrisse. London: Pluto Press.

Panitch L (1976) Social Democracy and Industrial Militancy: The Labour Party, the Trade Unions and Incomes Policy, 1945-1974. Cambridge: Cambridge University Press.

Papadopoulos D, Stephenson N, Tsianos V (2008) Escape Routes: Control and Subversion in the 21st Century. London: Pluto Press.

Rajchman J (2000) The Deleuze Connections. Cambridge, MA: MIT Press.

Read J (2003) The Micro-Politics of Capital: Marx and the Prehistory of the Present. New York: State University of New York Press.

Rhodes M (2000) Restructuring the British welfare state: Between domestic constraints and global imperatives. In Scharpf FW, Schmidt VA (eds.) Welfare and Work in the Open Economy. Volume II: Diverse Responses to Common Challenges. Oxford: Oxford University Press.

Shimizutani S, Yokoyama I (2009) Has Japan's long-term employment practice survived? Developments since the 1990s. Industrial and Labor Relations Review 62(3): 313-26.

Stanley L (2012) Crisis narration and off-loading responsibility: Displacing blame for the austerity in the UK. Paper presented at the BISA-IPEG conference, 'The Future of Global Economic Governance', Birmingham, 10-11 September.

Streeck W, Yamamura K (eds.) (2001) The Origins of Nonliberal Capitalism: Germany and Japan in Comparison. Ithaca, NY: Cornell University Press.

Streeck W, Yamamura K (eds.) (2003) The End of Diversity? Prospects for German and Japanese Capitalism. Ithaca, NY: Cornell University Press.

Suzuki M, Ito M, Ishida M, Nihei N, Murayama M (2010) Individualizing Japan: Searching for its origin in first modernity. British Journal of Sociology 61(3): 513-538. 
Tohyama H (2000) The capital-labour compromise and the financial system: A changing hierarchy. In Boyer R, Yamada T (eds.) Japanese Capitalism in Crisis: A Regulationist Interpretation. London: Routledge.

Tsianos V, Papadopoulos D, Stephenson N (2012) This is class war from above and they are winning it: What is to be done? Rethinking Marxism 24(3): 448-57.

Uemura H (2000) Growth, distribution and structural change in the post-war Japanese economy. In Boyer R, Yamada T (eds.) Japanese Capitalism in Crisis: A Regulationist Interpretation. London: Routledge.

Uni H (2000) Disproportionate productivity growth and accumulation regimes. In Boyer R, Yamada T (eds.) Japanese Capitalism in Crisis: A Regulationist Interpretation. London: Routledge.

Watson M (2008) Constituting monetary conservatives via the 'savings habit': New Labour and the British housing market bubble. Comparative European Politics 6(3): 285-304.

Yun J-W (2010) Unequal Japan: Conservative corporatism and labour market disparities. British Journal of Industrial Relations 48(1): 1-25.

\section{Author biographies}

David J. Bailey is a lecturer in political science at the University of Birmingham, UK. His research focuses on different forms of challenge to capitalism, including those of left parties and protest movements, within the contemporary European context. Recently published articles can be found in the Journal of Political Power and Journal of Critical Globalisation Studies.

Saori Shibata is a Ph.D. candidate in the Department of Political Science and International Studies at the University of Birmingham, UK. Her research interests focus on political economy, the comparative political economy of Japan, labour politics and social movements. 